\title{
THREE-DIMENSIONAL INTERPOLATION OF SOIL DATA: FERTILITY AND PEDOMORPHOLOGICAL FEATURES IN SOUTHERN BRAZIL ${ }^{(1)}$
}

\author{
Tales de Campos Piedade ${ }^{(2)}$, Vander de Freitas Melo ${ }^{(3)}$, Luiz Cláudio de Paula Souza $^{(3)}$ \& \\ Jeferson Dieckow ${ }^{(3)}$
}

\begin{abstract}
SUMMARY
The graphical representation of spatial soil properties in a digital environment is complex because it requires a conversion of data collected in a discrete form onto a continuous surface. The objective of this study was to apply three-dimension techniques of interpolation and visualization on soil texture and fertility properties and establish relationships with pedogenetic factors and processes in a slope area. The GRASS Geographic Information System was used to generate threedimensional models and ParaView software to visualize soil volumes. Samples of the $\mathrm{A}, \mathrm{AB}, \mathrm{BA}$, and $\mathrm{B}$ horizons were collected in a regular 122-point grid in an area of 13 ha, in Pinhais, PR, in southern Brazil. Geoprocessing and graphic computing techniques were effective in identifying and delimiting soil volumes of distinct ranges of fertility properties confined within the soil matrix. Both three-dimensional interpolation and the visualization tool facilitated interpretation in a continuous space (volumes) of the cause-effect relationships between soil texture and fertility properties and pedological factors and processes, such as higher clay contents following the drainage lines of the area. The flattest part with more weathered soils (Oxisols) had the highest $\mathrm{pH}$ values and lower $\mathrm{Al}^{3+}$ concentrations. These techniques of data interpolation and visualization have great potential for use in diverse areas of soil science, such as identification of soil volumes occurring sideby-side but that exhibit different physical, chemical, and mineralogical conditions for plant root growth, and monitoring of plumes of organic and inorganic pollutants in soils and sediments, among other applications. The methodological details for interpolation and a three-dimensional view of soil data are presented here.
\end{abstract}

Index terms: geoprocessing, GRASS GIS, ParaView, confined soil volume, soil acidity.

(1) Received for publication on July 16, 2013 and approved on April 25, 2014.

(2) Master in Soil Science, Federal University of Paraná, UFPR. Rua dos Funcionários, 1540, Cabral. CEP $80035-050$ Curitiba (PR), Brazil. E-mail: tales@eccoambiental.com.br

(3) Professor, Department of Soil and Agricultural Engineering, UFPR. E-mail: vanderfm@ufpr.br, lcsouza@ufpr.br, jefersondieckow@ufpr.br 


\title{
RESUMO: INTERPOLAÇÃO TRIDIMENSIONAL DE DADOS DE SOLOS: FERTILIDADE E CARACTERÍSTICAS PEDOMORFÓLOGICAS NO SUL DO BRASIL
}

\begin{abstract}
A representação gráfica dos atributos espaciais do solo em um ambiente digital é uma tarefa complexa, pois requer a conversão de dados coletados de forma discreta para uma superficie contínua. Os objetivos deste estudo foram aplicar técnicas tridimensionais de interpolação e visualização da textura e dos atributos de fertilidade do solo e estabelecer relações com fatores e processos pedogenéticos em uma área de encosta. Os programas GRASS $e$ ParaView foram utilizados para gerar modelos tridimensionais e visualizar volumes de solo, respectivamente. Amostras dos horizontes $A, A B, B A$ e $B$ foram coletadas em uma grade regular de 122 pontos em uma área de 13 ha, em Pinhais, PR, sul do Brasil. As técnicas de geoprocessamento e de computação gráfica foram eficientes para identificar e delimitar volumes de solo com faixas distintas de valores de atributos da fertilidade confinados dentro da matriz do solo. A interpolação tridimensional e a ferramenta de visualização facilitaram a interpretação em um espaço contínuo (volumes) das relações de causa-efeito entre a textura do solo e os atributos de fertilidade e os fatores e processos pedológicos, como os maiores teores de argila seguindo as linhas de drenagem da área. A parte mais plana, com ocorrência de solos mais intemperizados (Latossolos), apresentou os maiores valores de pH e as concentrações mais baixas de $\mathrm{Al}^{3+}$. Essas técnicas de interpolação e visualização de dados têm grande potencial para ser utilizada em diversas áreas da ciência do solo, como a identificação de volumes de solos que ocorrem lado a lado, mas que oferecem diferentes condições físicas, químicas $e$ mineralógicas para o crescimento das raizes das plantas; o monitoramento de plumas de poluentes orgânicos e inorgânicos em solos e sedimentos; entre outras aplicações. Os detalhes metodológicos para a interpolação e visualização em três dimensões de dados de solo foram apresentados neste trabalho.
\end{abstract}

Termos de indexação: geoprocessamento, GRASS GIS, ParaView, volume de solo confinado, acidez do solo.

\section{INTRODUCTION}

Physical and chemical phenomena act on parent material leading to progressive transformations that determine the morphological, physical, chemical, and mineralogical characteristics of the soil formed. Topography is also an important factor in the amount of water retained and the transport of solids or solution materials, producing different soil types (Curi \& Franzmeier, 1984). Soils from the same region and parent material may have distinct properties when located at different positions in the landscape and under diverse conditions of moisture, drainage, and relief (Schaefer et al., 2002), also providing them with distinct environmental and agricultural aspects (Reyniers et al., 2006; Chi et al., 2009).

Knowledge of soil spatial distribution, as well as the factors affecting such distribution, is fundamental for natural resource surveys and for the establishment and development of soil management strategies. Some studies have been conducted in soils derived from the same region and parent material as the current study (argillite of the Guabirotuba Formation, Curitiba, Parana, Brazil) aiming at determining the variability of the chemical and mineralogical characteristics in the landscape.

Oliveira Júnior et al. (2014) evaluated different soil sampling units on a slope (122 samples in georeferenced grid with a regular 30-m spacing) by using classical statistics and geoestatistics and concluded that the highest coefficients of variation occurred for $\mathrm{Al}^{3+}, \mathrm{P}$, and $\mathrm{K}^{+}(117,99$, and $78 \%$ respectively). The occurrence of drainage lines on slopes led to increases in organic carbon. In the mineralogical data, the total content of crystalline-Fe oxides was the property that showed the least spatial variability in the clay fraction.

The authors cited and several other environmental studies used $2 \mathrm{D}$ tools to assess spatial data distribution, following the classical form of geographical representation.

A digital, three-dimensional, and interactive environment has been used in an incipient form in studies involving soil survey data (Grunwald \& Barak, 2001; Delarue et al., 2009). Unlike other fields, such as medicine and those that study atmospheric phenomena, which make use of more sophisticated sensors able to collect data continuously, in soil science, interpolation of the data is necessary in order to produce continuous volumes (Neteler, 2001).

Since soil is a three-dimensional body (pedon), its spatial variation extrapolates the limits of the profile, either in horizontal or vertical directions. Analysis of the set of chemical properties can be made based on visualization techniques that allow such variations to be understood under a three-dimensional perspective. 
As examples of application of 3D evaluation in environmental studies, Grunwald \& Barak (2001) applied Virtual Reality Modeling Language (VRML) to create virtual $3 \mathrm{D}$ soil landscape and study relationships between soil horizons and terrain features. Delarue et al. (2009) also used a virtual environment to reconstruct the soil horizons in order to study spatial distribution in the landscape and, although they did not generate volumes, the threedimensional representation helped to interpret the evolution of pedogenetic soil horizons. Khan et al. (2012) estimated soil permeability and mapped the microstructures within the soil aggregates into threedimensional images in order to quantify the connectivity of the pore network, and Hu et al. (2013) developed a process to combine multiple horizontal layers and recreate a profile to view the paths of water flow in three dimensions in calcareous soil.

Three-dimensional data interpolations have also been used for environmental purposes. Ouyang et al. (2002) showed that $\mathrm{Pb}$ concentration decreased with depth in sediments of the Cedar River and Ortega River in Florida, USA, in a study to investigate the characteristics and 3D spatial distribution of heavy metals $(\mathrm{Pb}, \mathrm{Cu}, \mathrm{Zn}$, and $\mathrm{Cd})$.

The objective of this study was to apply threedimension techniques of interpolation and visualization to soil texture and fertility properties and establish their relationships with pedogenetic factors and processes in a slope area.

\section{MATERIALS AND METHODS}

\section{Field area, soil sampling, and analysis}

The experimental plot (13 ha) was located at the Experimental Station of the Universidade Federal de Paraná (Federal University of Paraná), municipality of Pinhais, in the Curitiba Metropolitan Region (CMR), Parana, Brazil (Figure 1) (688350 m E, 7189500 m $\mathrm{N} ; 688950 \mathrm{~m}$ E, $7190250 \mathrm{~m}$ N, UTM system, SAD 69 datum, $51^{\circ}$ W.G.)

The experimental station where the study was developed has been part of the environmental protection area of the Irai River since 1996. This is a protected area because it is within the bounds of a source of water supply for some cities of the Curitiba Metropolitan Region. Thus, activities involving soil management and farming in general have become quite restricted, the use of fertilizers and pesticides not being allowed. This study was conducted on a hillslope near a site with the presence of cattle before 1996, with the predominance of vegetation for grazing for over 30 years. There is no record of liming and animals in the area after 1996.

The hillslope orientation is SW-NE, with altitude ranging from 905 to $940 \mathrm{~m}$. The climate is designated as $\mathrm{Cfb}$ (Köppen classification), characterized as humid temperate with well-defined seasons and monthly rainfall ranging from $73 \mathrm{~mm}$ in August to $172 \mathrm{~mm}$ in January.

The two main soil types were Inceptisols, on the upper and most dissected portion of the landscape (Figure 1c), and Oxisols, on the footslope.

The geological lithostratigraphy included smectiterich argillite followed by sandy arkose deposits and small caliche horizons, typical of the local Guabirotuba geological formation (Salamuni \& Stellfeld, 2001). These sedimentary materials are derived from crystalline rocks which weathered under wet conditions and settled during semi-arid periods, over humid-dry cycles.

In accordance with relief and field observations, Oliveira Júnior et al. (2010) identified four distinct geomorphological surfaces in the study area: S01, S02, S03, and S04 at the 940, 935, 930, and $905 \mathrm{~m}$ altitudes, respectively. Surfaces S01 to S03 were delimited by small water dividers, which remained as evidence of previous erosion in the form of small crests, with convex divergent relief. In contrast, S04 represented a flat area which received the colluvial sediments (Figure 1c).

Soil was sampled following a regular 122-point grid, with $30 \mathrm{~m}$ spacing between points (Figure 1b). An undisturbed core-sample (cylinder) was taken from the 0 to $110 \mathrm{~cm}$ depth (10 cm diameter) at each sampling point using a PVC tube enclosed in a mechanical auger apparatus driven by a tractor power take-off.

After being removed, the PVC tube was cut lengthwise, and the sample was divided into two monoliths, where the $\mathrm{A}, \mathrm{AB}, \mathrm{BA}$, and $\mathrm{B}$ horizons where identified and morphologically described. Samples of the four horizons were separated, dried at $40^{\circ} \mathrm{C}$ for $24 \mathrm{~h}$, passed through a $2 \mathrm{~mm}$ mesh, and stored for further analysis. A total of 488 soil samples were used in the study (122 sampling points $\times 4$ horizons).

Soil texture was assessed by the pipette method (Gee \& Bauder, 1986). Samples were chemically analyzed to determine the following soil fertility attributes (Embrapa, 1997): $\mathrm{pH}$ in $\mathrm{H}_{2} \mathrm{O}$, exchangeable $\mathrm{Al}^{3+}, \mathrm{Ca}^{2+}$ and $\mathrm{Mg}^{2+}$ (extraction with $1 \mathrm{~mol} \mathrm{~L}^{-1} \mathrm{KCl}$ ), exchangeable $\mathrm{K}^{+}$(extraction with $0.05 \mathrm{~mol} \mathrm{~L}^{-1} \mathrm{HCl}+$ $0.025 \mathrm{~mol} \mathrm{~L}^{-1} \mathrm{H}_{2} \mathrm{SO}_{4}$ - Mehlich-1), non-exchangeable acidity $(\mathrm{H})$ (extraction with $0.5 \mathrm{~mol} \mathrm{~L}^{-1} \mathrm{Ca}(\mathrm{OAc})_{2}, \mathrm{pH}$ 7.0), and organic carbon (OC) (extraction with $\mathrm{H}_{2} \mathrm{SO}_{4}$ and sodium dichromate solution).

\section{Volume modeling of soil and visualization}

Soil fertility data were organized on a spreadsheet according to identification of the sampling point, the UTM geographic coordinates $(x, y)$, and sampling depth $(z)$. The $z$ parameter of each horizon had to be represented as a single value (discrete position), so it was considered as the depth of the upper limit of the horizon. Data was exported into the ASCII (American standard code for information interchange) format. 


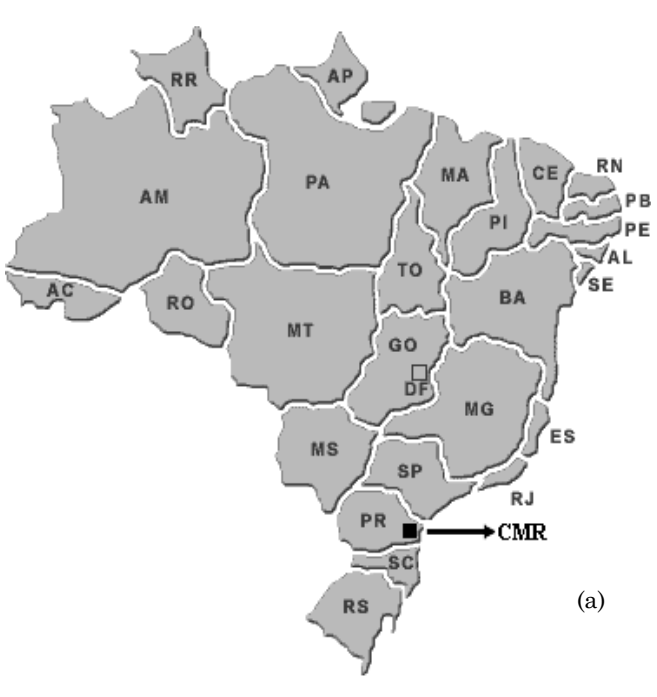

(a)

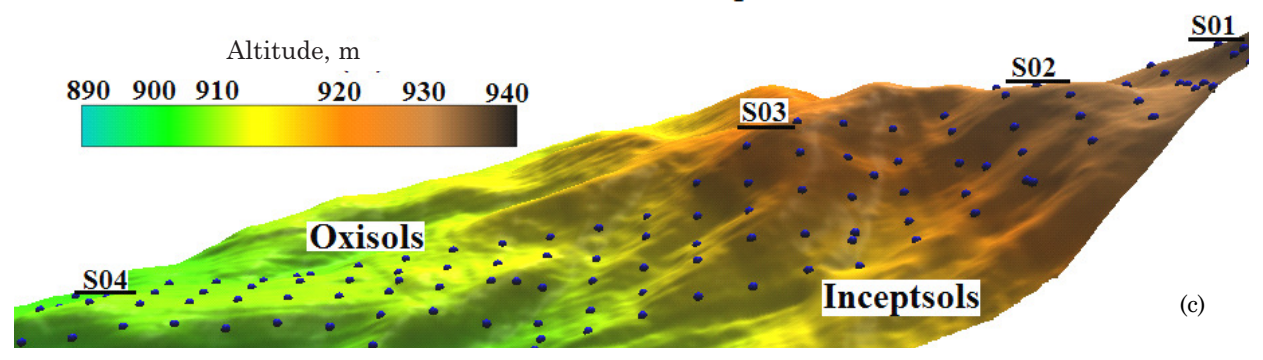

Figure 1. Map of Brazil indicating the state of Parana (PR) and the Curitiba Metropolitan Region (CMR) (a); distribution of sampling points over the study area (b); three dimensional view of the surface of the study area, showing two main morphological features where Oxisols and Inceptisols predominate (c), respectively.

To generate three-dimensional soil models, we used the GRASS GIS 6.3.0 software (Geographic Resources Analysis Support System) (GRASS Development Team, 2012). Before data import, a georeferenced environment was created in order to limit processing to only within the sampling site or bounding box (Figure 1b,c). This environment was set in a UTM coordinate system referred to as SAD 69 Datum, and the central meridian of $51^{\circ}$ W.G.

After data import, a mask (raster map) was created to cover and limit processing to only the sampling site. Soil fertility data were interpolated and represented in three-dimensional space through the regularized spline with tension (RST) method (Mitasova \& Hofierka, 1993; Mitasova \& Mitas, 1993). The spatial resolution was $2 \mathrm{~m}$ and, by default, the system adopts a tension of 40 and smoothness of 0.1 .

After interpolation, the resulting representation of soil volume was exported into the VTK (visualization toolkit) format for viewing with ParaView 3.6.0 software (Henderson, 2001). This procedure required the use of a mask for the 3D volume, which ensured that only data within the perimeter of the area was

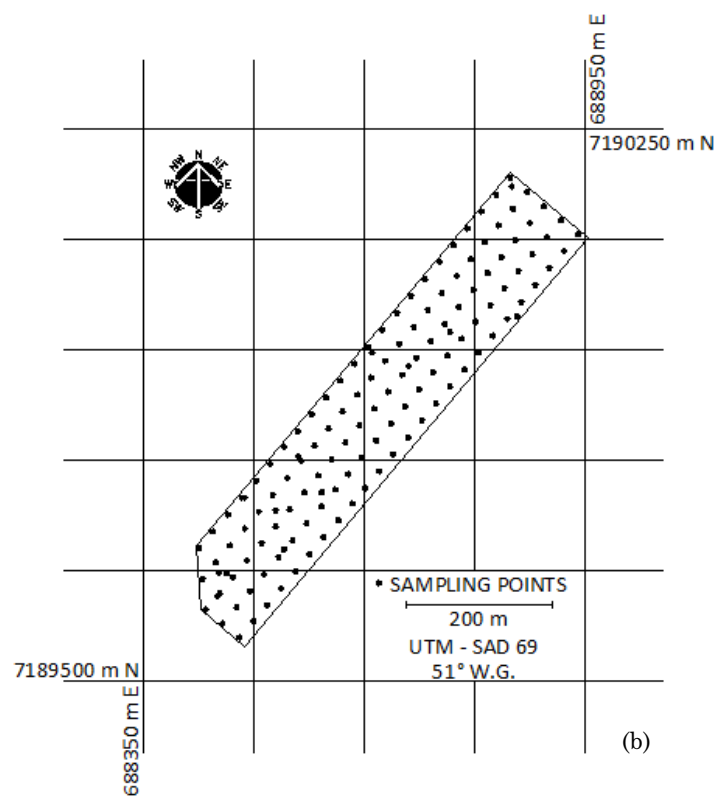

(b)

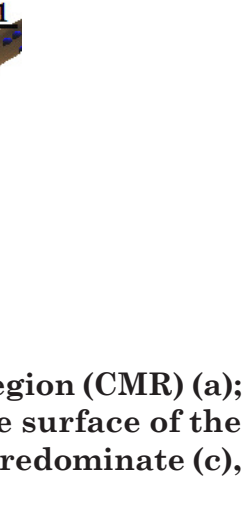


the S03 and S04 levels, where Oxisols predominate, especially associated with drainage lines located between erosion planes (Figure 2). Isolated soil volumes with clay content $>700 \mathrm{~g} \mathrm{~kg}^{-1}$ were also found in this portion (red volumes, Figure 3). Sand content, for its part, was higher mainly on ridges between S01 and S03, in accord with lower clay contents.

The higher clay content $\left(>600 \mathrm{~g} \mathrm{~kg}^{-1}\right)$ in the lower portion of the area, where Oxisols predominate (Figure 3), may be associated with a preferential deposition of fine colluvial material and with a more advanced weathering stage of the subsurface horizons.

The increase in clay in drainage lines (Figure 2) may be attributed to two processes, which are not mutually exclusive: i) dissection of the area, in which soil removal by erosion may have exposed deeper

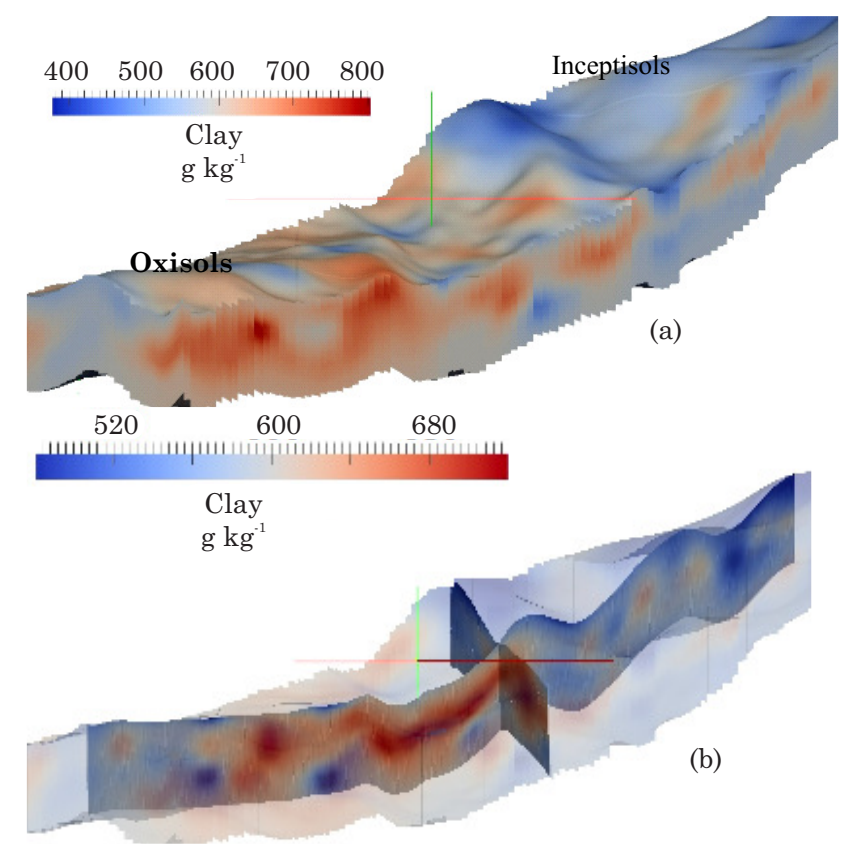

Figure 2. Spatial distribution of clay content in volume representation (a), and in longitudinal and transversal cross sections (b). Inceptisols occur in the upper portion of the landscape, and Oxisols in the lower.



Figure 3. Volume representation of the spatial distribution of clay content from 600 to $700 \mathrm{~g} \mathrm{~kg}^{-1}$ (light green), and $>700 \mathrm{~g} \mathrm{~kg}^{-1}$ (red). Inceptisols occur in the upper portion of the landscape, and Oxisols in the lower. horizons closer to the parent material (rich in clay), mainly in the valley bottoms of the drainage lines, as can be seen by the differential accumulation of clay in these positions in the longitudinal cross section (Figure 2b); ii) lateral migration of clay, as seen by the increase in clay content towards the drainage lines (transversal cross section, Figure 2b). Supporting this evidence, Oliveira Júnior et al. (2014), in a previous study, found lower water content, divergent convex relief forms, and higher index values of soil loss on the ridges of the terrain, defined as S01, S02, and S03 (Figure 1c).

\section{Soil acidity: $\mathrm{pH}$, exchangeable $\mathrm{Al}^{3+}$, and non- exchangeable $\mathrm{H}$}

All soil samples had an acidic character, with $\mathrm{pH}$ ranging from 4.8 to 6.0 (Figure $4 \mathrm{a}$ ), with 5.2 being the modal $\mathrm{pH}$ value (Figure $4 \mathrm{~b}$ ). There was no coincidence in the spatial distribution of $\mathrm{pH}$ and $\mathrm{Al}^{3+}$ (Figure 5). The highest $\mathrm{pH}$ values were observed up to the 20-cm depth, with the occurrence of some isolated volumes with $\mathrm{pH}>5.4$ in the soil subsurface (Figure 5). The highest $\mathrm{Al}^{3+}$ concentrations were observed from the 20 to $80 \mathrm{~cm}$ depth, with some isolated soil volumes $>4 \mathrm{cmol}_{\mathrm{c}} \mathrm{kg}^{-1}$ (red, Figure 5).

The main $\mathrm{Al}^{3+}$ source in these soils was possibly smectite, a major constituent of the argillite parent material (Guabirotuba Formation) (Salamuni \& Stellfeld, 2001). Melo et al. (2009) studied the mineralogical composition of the clay fraction of Inceptisols derived from this same argillite and found montmorillonite and beidellite (dioctahedral smectites with $\mathrm{Al}$ in the octahedral sheet) in the $\mathrm{C} 2, \mathrm{C} 3$, and $\mathrm{C} 4$ horizons, up to $4.5 \mathrm{~m}$ deep. Through diagenesis and neogenesis processes during weathering, smectite is transformed preferentially into 1:1 phyllosilicate (kaolinite) in subsurface horizons, with intense release of $\mathrm{Al}^{3+}$ (Juo \& KampratH, 1979; Thomas \& Hargrove, 1984).

In Oxisols of the footslope, the occurrence of soil volumes with $\mathrm{pH}<5.4$ or $\mathrm{Al}^{3+}>2.8 \mathrm{cmol}_{\mathrm{c}} \mathrm{kg}^{-1}$ were not as expressive as in the upper land (Figure 5). The low $\mathrm{Al}^{3+}$ concentrations in the footslope are attributed to more intense weathering, characterized by silica removal and the formation of gibbsite (Oliveira Júnior et al., 2014), and higher $\mathrm{pH}$ values. The low $\mathrm{Al}^{3+}$ concentration in highly weathered soils (Fox, 1982) has positive practical implications in terms of less lime requirements for crop production.

The lower $\mathrm{Al}^{3+}$ concentrations in the top $0-20 \mathrm{~cm}$ layer are attributed to three simultaneous factors: (i) the horizon is more weathered, with $\mathrm{Al}^{3+}$ being transformed into gibbsite (Motta \& Melo, 2009); (ii) higher contents of organic matter, which complexes $\mathrm{Al}^{3+}$ (Simas et al., 2007); and (iii) higher $\mathrm{pH}(>5.4)$, inducing $\mathrm{Al}$ precipitation (Pionke \& Corey, 1967). In the top layer, there are extensive soil volumes with $\mathrm{pH}>5.4$ (Figures 4 and 5) and OC contents $>25 \mathrm{~g} \mathrm{~kg}^{-1}$ (Figure 6) that do not coincide with surfaces that 

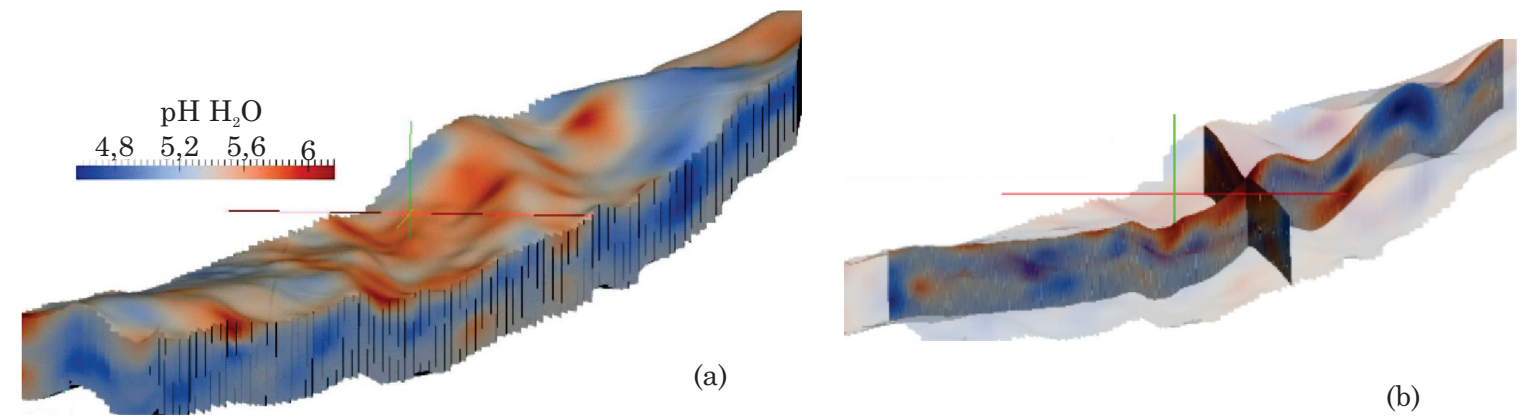

(a)

(b)

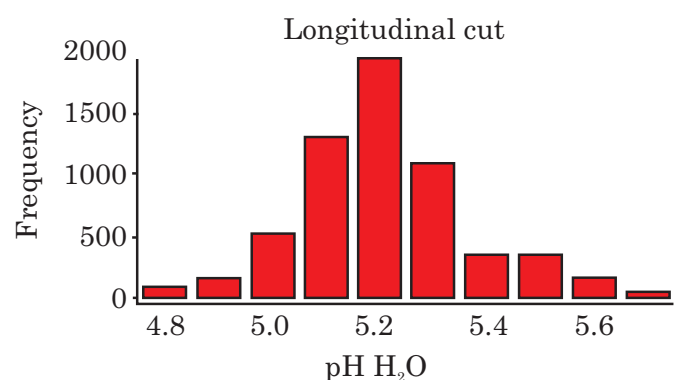

(b)

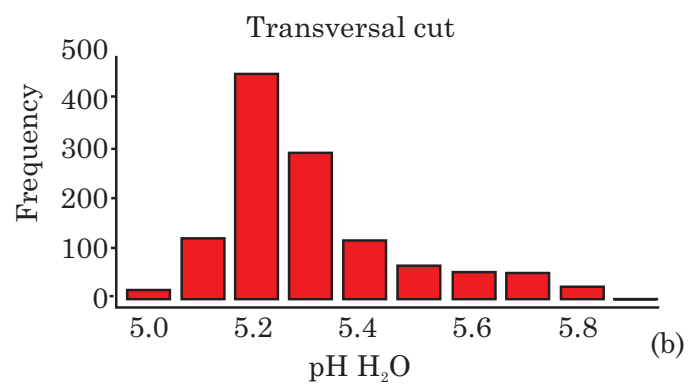

Figure 4. Spatial distribution of $\mathrm{pH}$ value, in whole volume representation (a), and in longitudinal and transversal cross sections and their respective frequency distributions (b). Inceptisols occur in the upper portion of the landscape, and Oxisols in the lower.

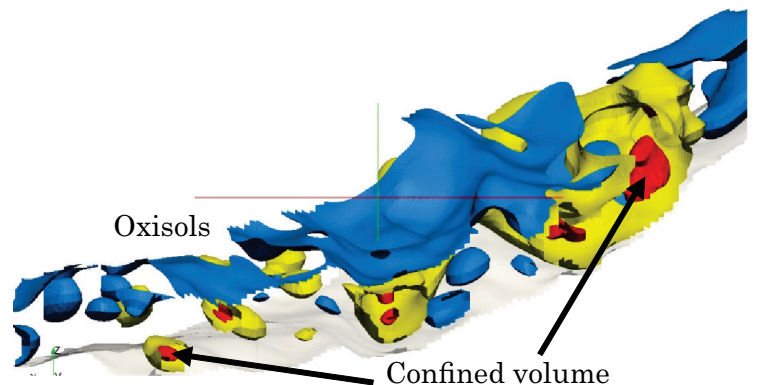

(a)

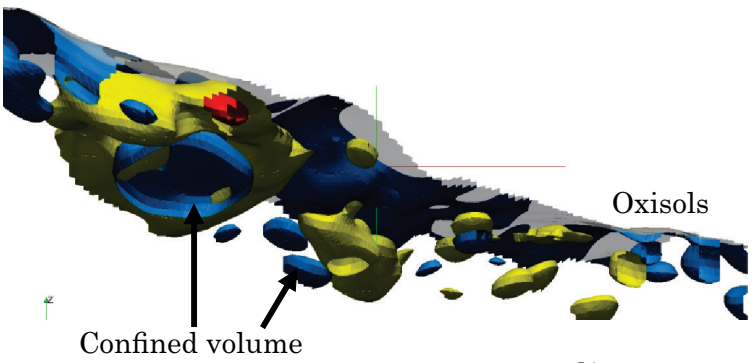

(b)

Figure 5. Opposite spatial relationship between $\mathrm{pH}$ values and $\mathrm{Al}^{3+}$ contents: volume representation in a lateral (a) and basal (b) view of $\mathrm{pH}>5.4$ (blue), $\mathrm{Al}^{3+}$ from 2.8 to $3.9 \mathrm{cmol}_{\mathrm{c}} \mathrm{kg}^{-1}$ (yellow), and $\mathrm{Al}^{3+}>4.0 \mathrm{cmol}_{\mathrm{c}}$ $\mathrm{kg}^{-1}$ (red). Inceptisols occur in the upper portion of the landscape, and Oxisols in the lower.
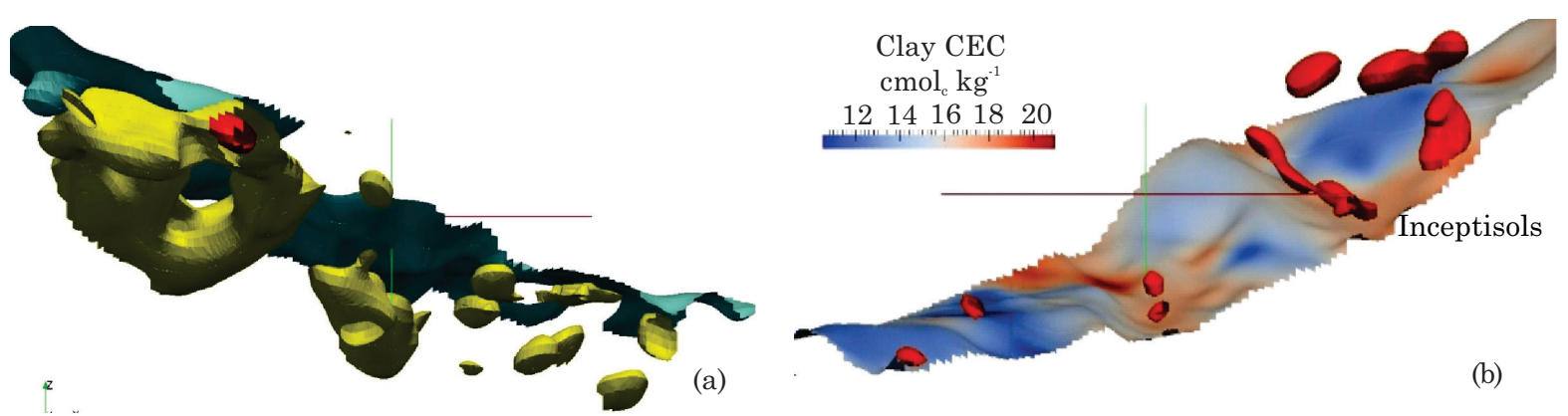

Figure 6. Volume representation of the spatial distribution of organic carbon $>25 \mathrm{~g} \mathrm{~kg}^{-1}(\mathrm{blue})$, Al ${ }^{3+} \mathrm{between}^{-}$ 2.8 and $3.9 \mathrm{cmol}_{\mathrm{c}} \mathrm{kg}^{-1}$ (yellow) and $>4.0 \mathrm{cmol}_{\mathrm{c}} \mathrm{kg}^{-1}$ (red) (a); and of $\mathrm{Al}^{3+}>4.0 \mathrm{cmol}_{\mathrm{c}} \mathrm{kg}^{-1}$ (red) and the horizontal distribution of the clay fraction CEC at $80-\mathrm{cm}$ depth (b). Inceptisols occur in the upper portion of the landscape, and Oxisols in the lower. 
represent the highest $\mathrm{Al}^{3+}$ concentrations. According to Conyers (1990) and Rodeja et al. (2004), the extraction of $\mathrm{Al}^{3+}$ specifically bound to functional groups of the organic matter (inner sphere complex) requires molar solutions with a stronger extraction capacity than $\mathrm{KCl}$, like $\mathrm{CuCl}_{2}$.

There was a predominance of soil volumes with $\mathrm{Al}^{3+}>4.0 \mathrm{cmol}_{\mathrm{c}} \mathrm{kg}^{-1}$ in drainage lines of the upper land (Inceptisols) (Figure 6b). The subsurface layer (80 $\mathrm{cm}$ depth) in these drainage lines accumulated Si from lateral and vertical flows, which led to favorable conditions for maintaining the smectite derived from the parent material (argillite), and thus the formation of less developed soils. The higher cation exchange capacity (CEC) of the clay fraction in drainage lines (Figure 6b) suggests the occurrence of $2: 1$ expansive minerals. Therefore, smectite would buffer the higher $\mathrm{Al}^{3+}$ concentrations in these parts of the landscape (Turner \& Brydon, 1967; Pratt et al., 1969; Thomas \& Hargrove, 1984; Motta \& Melo, 2009).

There was a close association between $\mathrm{OC}$ and $\mathrm{H}$ contents (Figure 7a). In the upper parts (better drained areas and lower OC content), the volume of lower $\mathrm{H}$ concentrations extended up to the surface soil. The functional groups of organic matter and $\mathrm{pH}$-dependent variable charges of the clay fraction minerals (kaolinite and $\mathrm{Fe}$-and $\mathrm{Al}$-oxides) are main sources of covalent $\mathrm{H}$ - dissociation of carboxylic and phenol groups from humic substances (Dick et al., 2002; Novotny et al., 2006), and of silanol (-SiOH), aluminol $(-\mathrm{AlOH})$ and the iron group $(-\mathrm{FeOH})$ from clay fraction minerals (Tarì et al., 1999).

\section{Soil cation exchange capacity (CEC) at pH 7.0}

Higher soil CEC was observed near the soil surface and landscape portions close to the drainage lines (Figure 7b), which coincides with portions of higher OC contents (Figure 7c). Pei et al. (2010) and Hancock et al. (2010) found higher organic matter accumulation in areas with a higher wetness index, a factor that delays the decomposition process. Furthermore, Moore et al. (1993), using the wetness index and slope gradient, found high correlations between these topographic indices and organic matter content, sand content, and A horizon depth.

At greater depth, with little influence from organic matter, an expressive effect of the quality of the clay fraction was observed - higher soil CEC at $\mathrm{pH} 7.0$ (figure not shown) and higher clay fraction activity (clay CEC) in drainage lines (plane at $80 \mathrm{~cm}$ depth, Figure 6b).

\section{$\mathrm{Ca}^{2+}$ and $\mathrm{Mg}^{2+}$ contents}

The highest $\mathrm{Ca}^{2+}$ and $\mathrm{Mg}^{2+}$ concentrations, both in the surface and depth layers (Figure 8), occurred in portions of higher organic matter accumulation and higher soil CEC at $\mathrm{pH} 7.0$ values in drainage lines (Figure 7b,c). Possibly, these exchangeable bases
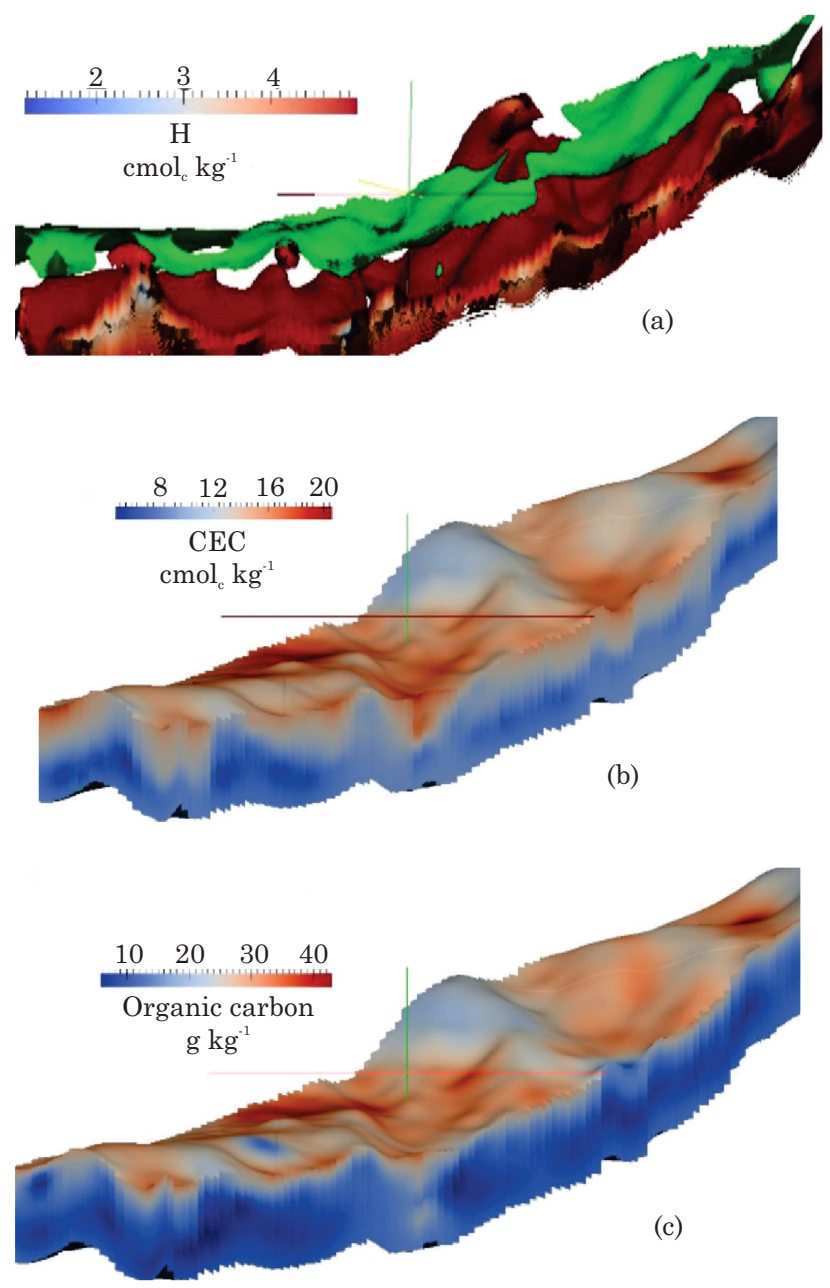

Figure 7. Volume representation of the spatial distribution of organic carbon $>25 \mathrm{~g} \mathrm{~kg}^{-1}$ (green) and of $\mathbf{H}<5.0 \mathrm{cmol}_{\mathrm{c}} \mathrm{kg}^{-1}$ (in colors which vary according to indications in the key) (a); of CEC at pH 7.0 (b); and of whole organic carbon (c). Inceptisols occur in the upper portion of the landscape, and Oxisols in the lower.

were leached from higher and convex portions towards lower portions of higher adsorption capacity. In spite of the same trend in the surface, the $\mathrm{Ca}^{2+}$ and $\mathrm{Mg}^{2+}$ concentrations were lower at the $100 \mathrm{~cm}$ depth (Figure 8).

Due to the higher adsorption strength of $\mathrm{Ca}^{2+}$ compared to $\mathrm{Mg}^{2+}$, the Ca:Mg ratio in the surface soil, at the higher frequency of each one $\left(4.0 \mathrm{cmol}_{\mathrm{c}} \mathrm{kg}^{-1} / 2.1\right.$ $\mathrm{cmol}_{\mathrm{c}} \mathrm{kg}^{-1}$ ), was higher than that observed at $100 \mathrm{~cm}$ (1.3 $\mathrm{cmol}_{\mathrm{c}} \mathrm{kg}^{-1} / 1.0 \mathrm{cmol}_{\mathrm{c}} \mathrm{kg}^{-1}$ ) (Figure 8), suggesting a greater leaching and accumulation of $\mathrm{Mg}^{2+}$ in the subsurface.

The higher $\mathrm{Mg}^{2+}$ concentrations at the end of the main drainage route at the $100 \mathrm{~cm}$ depth, which divide the region of Oxisols from the regions of Inceptisols (Figure 8g) could also be attributed to preferential leaching of this cation in relation to $\mathrm{Ca}^{2+}$. 

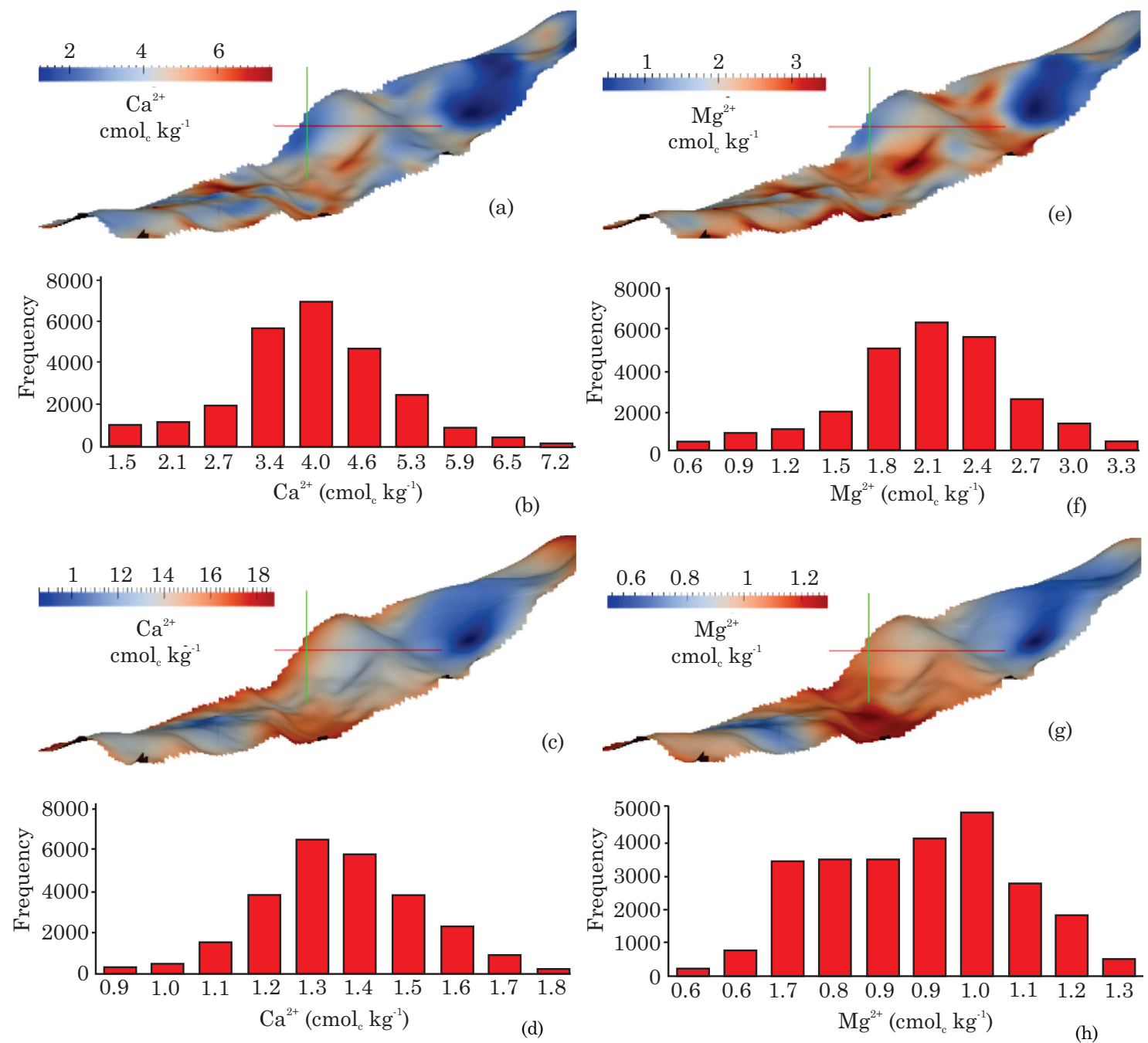

Figure 8. Horizontal distribution of $\mathrm{Ca}^{2+}$ concentration in the surface soil (a) and its frequency distribution (b); and at the 100-cm depth (c) and its frequency distribution (d); and distribution of $\mathrm{Mg}^{2+}$ concentration in the surface soil (e) and its frequency distribution (f); and at the 100-cm depth (g) and its frequency distribution (h). Inceptisols occur in the upper portion of the landscape, and Oxisols in the lower position.

The volumes with higher $\mathrm{Ca}^{2+}+\mathrm{Mg}^{2+}$ concentrations and higher base saturation $(\mathrm{V})$ values did not coincide with the higher $\mathrm{Al}^{3+}$ concentrations (Figure 9a) or the higher $\mathrm{Al}^{3+}$ saturation values (Figure 9b), respectively. This trend opposes the common generalization that highly weathered soils of the tropics are very acid (Lopes \& Cox, 1977). However, the effect of the form of relief on these relationships should also be considered (Kämpf \& Curi, 2012), where the higher contents of $\mathrm{Ca}^{2+}+\mathrm{Mg}^{2+}$ tend to follow the drainage lines of the area (Figure 8).

For the purpose of agricultural use, the flat lowland area with greater occurrence of more weathered soils (basal view- Oxisols) would require less lime. The ringshaped volume with higher $\mathrm{Al}^{3+}$ concentrations (yellow) was similar to the volume with higher $\mathrm{Al}^{3+}$ saturation (m) (red) within the $\mathrm{Ca}^{2+}+\mathrm{Mg}^{2+}$ concentrations and base saturation surfaces, respectively (Figure 9a,b).
Three-dimensional distribution allowed visualization of volumes with better soil chemical conditions, as seen in the basal view of the distribution of base saturation (V) (Figure 9b). Near the most central line of the area (limit between Oxisols and Inceptisols), there are better growing conditions due to the greater projection of the volume of higher base saturation values (23 to $68 \%$ ) towards the deeper horizons. Nevertheless, even in this region, plants growing side-by-side can find different fertility conditions due to the variation in the volumes of base saturation values.

The use of geoprocessing and graphic computing enabled visualization of the distribution of fertility properties in three-dimensional space, allowing observation of the extension of internal volumes with differentiated values/concentrations confined within the soil matrix. These techniques have great potential for more extensive use in diverse areas of soil science, 


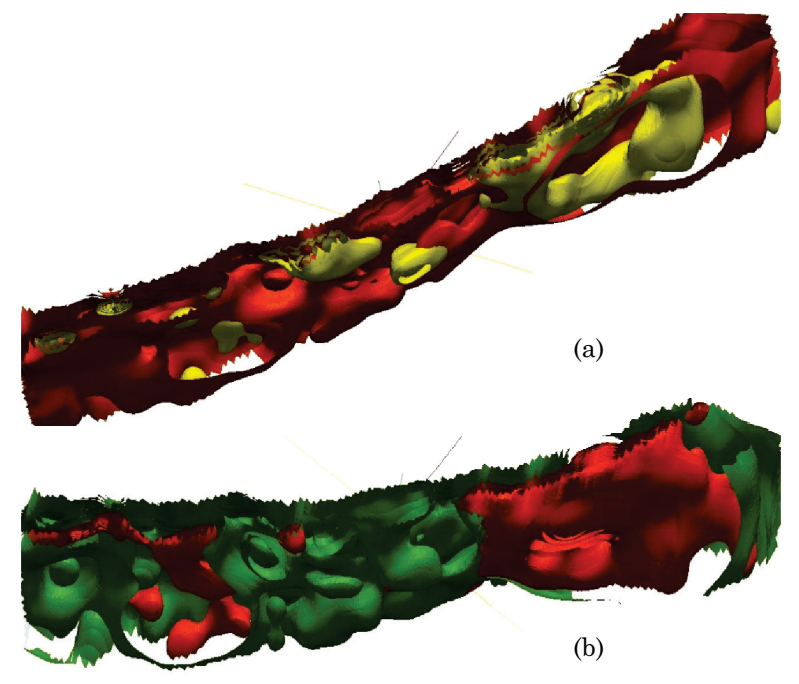

Figure 9. Volume representation of the spatial distribution of the highest $\mathrm{Ca}^{2++} \mathrm{Mg}^{2+}$ concentrations (2.1 to $\left.10.8 \mathrm{cmol}_{\mathrm{c}} \mathrm{kg}^{-1}\right)$ (orange) and of the highest $\mathrm{Al}^{3+}\left(>2.8 \mathrm{cmol}_{\mathrm{c}} \mathrm{kg}^{-1}\right)$ concentrations (yellow) (a); and of base saturation (V) from $23 \%$ to the highest value of $68 \%$ (green), and of $\mathrm{Al}^{3+}$ saturation (m) from $60 \%$ to the highest value of $83 \%$ (red) (b). Inceptisols occur in the upper portion of the landscape, and Oxisols in the lower.

for example, identification of soil volumes occurring side-by-side but which offer different conditions for plant root growth; and monitoring of plumes of organic and inorganic pollutants in soils and sediments.

\section{CONCLUSIONS}

1. The 3D tools enabled visualization and interpretation in a continuous space (volumes) of the cause-effect relations between chemical properties and pedogenetic factors and processes.

2. Higher clay content in drainage lines and in flat portions of the terrain, and higher sand content on ridge positions are attributed to internal clay migration and to erosion processes.

3. The preferential flow of water towards the drainage lines favored the accumulation of organic matter in the surface layer and of more clay activity in the subsurface layer (confined volumes of soils with higher clay CEC).

\section{LITERATURE CITED}

HENDERSON, A.S. The ParaView guide: A parallel visualization application. Clifton Park, New York, Kitware, 2007.

CHI, B.L.; BING, C.S.; WALLEY, F. \& YATES, T. Topographic indices and yield variability in a rolling landscape of western Canada. Pedosphere, 19:362-370, 2009.
CONYERS, M. The control of aluminum solubility in some acidic Australian soils. J. Soil Sci., 41:142-156, 1990.

CURI, N. \& FRANZMEIER, D.P. Toposequence of Oxisols from the Central Plateau of Brazil. Soil Sci. Soc. Am. J., 48:341-346, 1984.

DELARUE, F.; CORNU, S.; DAROUSSIN, J.; SALVADORBLANES, S.; BOURENNANE, H.; ALBÉRIC, P.; VENNINK, A.; BRUAND, A. \& KING, D. 3D representation of soil distribution: An approach for understanding pedogenesis. Compts Rendus Geosci., 341:486-494, 2009.

DICK, D.P.; MANGRICH, A.S.; MENEZES, S.C. \& PEREIRA, B. Chemical and spectroscopical characterization of humic acids from two south Brazilian coals of different ranks. J. Braz. Chem. Soc., 13:177-184, 2002.

EMPRESA BRASILEIRA DE PESQUISA AGROPECUÁRIA . EMBRAPA. Manual de métodos de análise de solo. 2.ed. Rio de Janeiro, 1997. 212p.

FOX, R.L. Some highly weathered soils of Puerto Rico: 3 Chemical properties. Geoderma, 27:139-176, 1982.

GEE, G.W. \& BAUDER, J.W. Particle-size analysis. In: KLUTE, A., ed. Methods of soil analysis: Physical and mineralogical methods. Madison, SSSA, 1986. Part 1, p.383-411.

GRASS Development Team. Geographic Resources Analysis Support System (GRASS) Programmer's Manual. Open Source Geospatial Foundation, 2012 Available at: <http:// grass.osgeo.org/programming6/>. Accessedn: Aug. 11, 2012.

GRUNWALD, S. \& BARAK, P. The use of VRML for virtual soil-landscape modeling. Syst. Anal. Modell. Simulation, 41:755-776, 2001.

HANCOCK, G.R.; MURPHY, D. \& EVANS, K.G. Hillslope and catchment scale soil organic carbon concentration: An assessment of the role of geomorphology and soil erosion in an undisturbed environment. Geoderma, 155:36-45, 2010.

HU, B.; HAN, C.-L.; JIA, Y.; ZHAO, Z.-H.; LI, F.-M. \& SIDDIQUE, K.H.M. Visualization of the threedimensional water-flow paths in calcareous soil using iodide water tracer, Geoderma, 200/201, p.85-89, 2013.

JUO, A.S.R. \& KAMPRATH, E.J. Copper chloride as an extractant for estimating the potentially reactive aluminum pool in acid soils. Soil Sci. Soc. Am. J., 43:35-38, 1979.

KÄMPF, N. \& CURI, N. Formação e evolução dos solos (Pedogênese). In: KER, J.C.; CURI, N.; SCHAEFER, C.E. \& TORRADO, P.V., eds. Pedologia. Viçosa, MG, Sociedade Brasileira de Ciência do Solo, 2012. p.222-230.

KHAN, F.; ENZMANN, F.; KERSTEN, M.; WIEGMANN, A. \& STEINER, K. 3D simulation of the permeability tensor in a soil aggregate on basis of nanotomographic imaging and LBE solver. J. Soils Sediments, 12:86-96, 2012.

LOPES, A.S. \& COX, F.R. A survey of the fertility status soils under "Cerrado" vegetation in Brazil. Soil Sci. Soc. Am. J., 41:742-746, 1977.

MELO, V.F.; MATTOS, J.M. \& LIMA, V.C. Methods for concentrating secondary $2: 1$ minerals in the clay fraction for subsequent identification by X-ray diffractometry. R. Bras. Ci. Solo, 33:527-539, 2009. 
MITASOVA, H. \& MITAS, L. Interpolation by regularized spline with tension: I. Theory and implementation. Math. Geol., 25:641-656, 1993.

MITASOVA, H. \& HOFIERKA, J. Interpolation by regularized spline with tension: II. Application to terrain modeling and surface geometry analysis. Math. Geol., 25:657-669, 1993.

MOORE, I.D.; GESSLER, P.E.; NIELSEN, G.A. \& PETERSON, G.A. Soil attribute prediction using terrain analysis. Soil Sci. Soc. Am. J., 57:443-452, 1993.

MOTTA, A.C.V. \& MELO, V.F. Química dos solos ácidos. In: MELO, V.F. \& ALLEONI, L.R.F., edS. Química e mineralogia do solo. Parte I - Conceitos básicos. Viçosa, MG, Sociedade Brasileira Ciência do Solo, 2009. p.428-497.

NETELER, M. Volume modelling of soils using GRASS GIS $3 \mathrm{D}$ tools. In: BROVELLI, M., ed. The geomatics workbook, n.2. Milano, Politecnico di Milano, 2001. n.p.

NOVOTNY, E.H.; KNICKER, H.; COLNAGO, L.A. \& MARTIN-NETO, L. Effect of residual vanadyl on the spectroscopic analysis of humic acids. Org. Geochem., 37:1562-1572, 2006.

OLIVEIRA JÚNIOR, J.C.; SOUZA, L.C.P. \& MELO, V.F. Variabilidade de atributos físicos e químicos de solos da Formação Guabirotuba em diferentes unidades de amostragem. R. Bras. Ci. Solo, 34:1491-1502, 2010.

OLIVEIRA JÚNIOR, J.C.; SOUZA, L.C.P.; MELO, V.F. \& ROCHA, H.O. Topographic indices and spatial distribution of soil mineralogical attributes. Geoderma, 213:214-225, 2014.

OUYANG, Y.; HIGMAN, J.; THOMPSON, J.; O’TOOLE, T. \& CAMPBELL, D. Characterization and spatial distribution of heavy metals in sediment from Cedar and Ortega rivers subbasin. J. Contam. Hydrol., 54:19-35, 2002.

PEI, T.; QIN, C.; ZHU, A.; YANG, L.; LUO, M.; LI, B. \& ZHOU, C. Mapping soil organic matter using the topographic wetness index: A comparative study based on different flow-direction algorithms and kriging methods. Ecol. Indicators, 10:610-619, 2010.
PIONKE, H.B. \& COREY, R.B. Relations between acidic aluminum and soil $\mathrm{pH}$, clay and organic matter. Soil Sci. Soc. Am. Proc., 31:749-752, 1967.

PRATT, P.F.; PETERSON, F.F. \& HOLZHEY, C.S. Qualitative mineralogy and chemical properties of a few soils from São Paulo, Brazil. Turrialba, 19:491-496, 1969.

REYNIERS, M.; MAERTENS, K.; VRINDTS, E. \& BAERDEMAEKER, J. Yield variability related to landscape properties on loamy soil of central Belgium. Soil Till. Res., 88:262-273, 2006.

RODEJA, E.G.; NOVOA, J.C.; PONTEVEDRA, X.; CORTEZAS, A.M. \& BUURMAN, P. Aluminum fractionation of European volcanic soils by selective dissolution techniques. Catena, 56:155-183, 2004.

SALAMUNI, E. \& STELLFELD, M.C. Banco de dados geológicos geo-referenciados da Bacia Sedimentar de Curitiba (PR) como base de sistema de informação geográfica (SIG). B. Paranaense Geoci., 49:21-32, 2001.

SCHAEFER, C.E.; KER, J.C.; CAMPOS, J.C.F.; COSTA, L.M. \& GILKES, R. Pedogenesis on the uplands of the Diamantina Plateau: a chemical and micropedological study. Geoderma, 107:93-119, 2002.

SIMAS, F.N.B.; SCHAEFER, C.E.; MELO, V.F.; ALBUQUERQUE-FILHO, M.R.; MICHEL, R.F.M.; PEREIRA, V.V.; GOMES, M.R.M. \& COSTA, L.M. Ornithogenic cryosols from Maritime Antarctica: Phosphatization as a soil forming process. Geoderma, 138:191-203, 2007.

TARÌ, G.; BOBOS. I.; GOMES, C.S.F. \& FERREIRA, J.M.F. Modification of surface charge properties during kaolinite

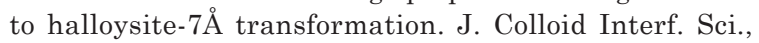
210:360-366, 1999.

THOMAS, G.W. \& HARGROVE, W.L. The chemistry of soil acidity. In: ADAM, F., ed. Soil and liming. Madison, American Society of Agronomy, 1984. p.3-55.

TURNER, R.C. \& BRYDON, J.E. Removal of interlayer aluminum hydroxide from montmorillonite by seeding the suspension with gibbsite. Soil Sci., 104:332-335, 1967. 